\title{
Respondent's Characteristic and Noise Intensity as Predicting Factors of Noise Induced Hearing Loss
}

\author{
Karakteristik Responden dan Intensitas Kebisingan sebagai Faktor Prediksi \\ Gangguan Pendengaran Akibat Bising
}

\author{
Decy Situngkir, Ira Marti Ayu, Laosma Sipahutar \\ Public Health Major, University of Esa Unggul \\ Jl. Arjuna Utara No.9, West Jakarta, 11510 Indonesia
}

\begin{abstract}
Introduction: Sensorineural hearing loss caused by loud noise exposure for a long time is known as the risk of experiencing Noise-Induced Hearing Loss. PT. Multi Karya Asia Pacific Raya (PT. MKAPR) is a company that provides products and services to the oil and gas industry in Indonesia. Based on its medical check-up, workshop workers at PT MKAPR have the risk of experiencing Noise-Induced Hearing Loss. The Lodan-9 Workshop area was known to have different noise levels, 88-91 dB in the fabrication, pump and engineering areas, and 90-102 $\mathrm{dB}$ in the function test area. The purpose of this study was to identify predicting factors of Noise-Induced Hearing Loss at PT. MKAPR. Method: This study used a case-control design. The population in this study were 26 cases and 48 control. Sample size in this study consisted of 26 cases and 26 control. We used a purposive technique sampling. Data were collected through questionnaire, and then were analyzed by using Chi-Square Test. Result: There were association between noise intensity (P-value: 0.035 OR: 4.714; 95\% CI: 1.266-17.561), and work period (P-value: 0.029; OR 5.622; 95\% CI: 1.342-23.55) with the incidence of Noise-Induced Hearing Loss. Meanwhile age of workers (P-value: 1; OR: 1.547; 95\% CI: 0.336-2.976) and smoking habits (P-value: 0.465; OR: 0.435; 95\% CI: 0.096-1.168) have no relationship with the incidence of NoiseInduced Hearing Loss. Conclusion: Noise intensity and work period were predictors of Noise-Induced Hearing Loss on PT.MKAPR' workers. The longer the workers work in high noise intensity area, the more they are at risk of experiencing Noise-Induced Hearing Loss.
\end{abstract}

Keywords: ear, noise-induced hearing loss, noise, noise intensity

\section{ABSTRAK}

Pendahuluan: Gangguan pendengaran tipe sensorineural yang disebabkan oleh pajanan bising yang cukup keras dalam jangka waktu yang lama dikenal dengan Ganguan pendengaran akibat bising. PT. Multikarya Asia Pasific Raya (PT. $M K A P R)$ merupakan perusahaan yang menyediakan produk dan layanan untuk industri minyak dan gas di Indonesia. Berdasarkan hasil medical check up, pekerja workshop di PT MKAPR memiliki risiko mengalami gangguan pendengaran akibat bising. Pada area Workshop Lodan-9 diketahui memiliki tingkat kebisingan yang berbeda, yaitu 88-91 dB pada area fabrikasi, pompa dan engineering, serta 90-102 dB di function test area. Penelitian ini bertujuan untuk mengidentifikasi faktor-faktor yang berhubungan dengan kejadian gangguan pendengaran akibat bising. Metode: Penelitian ini menggunakan desain penelitian kasus-kontrol. Populasi kasus pada penelitian ini sebanyak 26 orang dan populasi kontrol sebanyak 48 orang. Sampel kasus dalam penelitian ini sebanyak 26 orang) dan sampel kontrol sebanyak 26 orang. Teknik pengambilan sampel dengan teknik purposive. Data dikumpulkan dengan menggunakan kuesioner, kemudian dianalisa dengan menggunakan uji chi kuadrat. Hasil: Ada hubungan yang signifikan antara intensitas kebisingan (Pvalue : 0,035 ; OR : 4,714 ; 95\% CI : 1,266-17.561) dan masa kerja (Pvalue : 0,029; OR 5,622 ; 95\% CI : 1,342-23,55) dengan kejadian gangguan pendengaran akibat bising. Sedangkan usia (Pvalue : 1 ; OR : 1,547, 95\% CI : 0,336-2,976) dan kebiasaan merokok (Pvalue : 0,465; OR : 0,435; 95\% CI : 0,096-1,168) tidak memiliki hubungan dengan kejadian gangguan pendengaran akibat bising. Simpulan: Intensitas kebisingan dan masa kerja merupakan penyebab pekerja mengalami gangguan pendengaran akibat bising. Semakin lama pekerja bekerja dengan intensitas kebisingan yang tinggi, maka semakin besar kemungkinan pekerja mengalami gangguan pendengaran akibat bising.

Kata kunci: gangguan pendengaran akibat bising, kebisingan, tingkat kebisingan, telinga

\section{Corresponding Author:}

Decy Situngkir

Email: decy.situngkir@esaunggul.ac.id

Telephone: +628983697021

(C2020 IJOSH All right reserved. Open access under CC BY NC-SA license doi: 10.20473/ijosh.v9i3.2020.239-247 Received December 28, 2019, received in revised form October 31, 2020, Accepted October 31, 2020, Published: November 2020 


\section{INTRODUCTION}

Primarily, a sensorineural type of hearing loss caused by loud noise exposure for long time is known as Noise-Induced Hearing Loss. However, it is not an acoustic trauma or physical injury to the ear, and usually it is due to a noisy work environment that makes a problem to the auditory nerve which delivers sounds to brain. Noise or unwanted sound is a form of vibration that arises through solid objects, liquids or gases that can cause health and environmental comfort disorder at a certain level and time. Noise effects on humans include psychological effects such as disturbing concentration, sleep or relaxation; physiological effects such as Noise-Induced Hearing Loss, aural pain; and speech communication disorders ((Salami et al ., 2015), (Plog et al ., 2012)).

In 2019, the world health organization stated that $5 \%$ of the world population or 466 million people experienced hearing loss. They also predicted that around 900 million people or one out of every ten people will have disabling hearing loss. The Australian Government in January 2012 stated that $37 \%$ of hearing loss cases was due to excessive noise. The prevalence of hearing loss in Southeast Asia is 156 million people or $27 \%$ of the total population while adults under 65 years are 49 million people or $9.3 \%$ caused by loud noise produced at work. According to the National Committee for the Prevention of Hearing Loss and Deafness in 2014, Noise-Induced Hearing Loss in Indonesia is among the highest in Southeast Asia which is around 36 million people or $16.8 \%$ of the total population (Sulaiman, 2017).

Based on the results of basic health research (Basic Health Research) in 2013, the prevalence of hearing loss due to noise in Indonesia was 2.9\%. The highest prevalence was found in West Nusa Tenggara province at $2.6 \%$ and the lowest prevalence was in Banten province at $1.6 \%$. Based on the age group, the highest prevalence was in the age group of 75 years old and above (36.6\%), followed by the age group of 65-74 years old (17.1\%), while the smallest prevalence was in the age group of 5-14 years old and $15-24$ years old $(0.8 \%$ each $)$. Based on the gender, the prevalence of respondents with hearing loss in women tended to be slightly higher than men (2.8\%:2.4\%) (Ministry of Health, 2013).

Ears are the organs that process sounds, enabling the brain to interpret what the individual is hearing. The ear is divided into three parts: outer ear, middle ear, and inner ear. Each of them has a unique function in the process of hearing. In simple terms, the outer and middle ears amplify the sound signal (vibration) and the inner ear converts this sound signal into an electrical impulse that is transmitted to the brain. This process also produces a frequency (or pitch) and intensity (or loudness) analysis of the sound signal (Ding et al ., 2019).

Noise-Induced Hearing Loss caused by noise occurs when the noise intensity is very high which results in mechanical damage to the cochlea. Powerful noise energy is transmitted to the inner ear and causes the perilymph and endolymph to fluctuate violently. The basilar membrane and the tectorial membrane shear and squeeze strongly, which separates the cilia from the inner and outer hair cells, making it difficult for the hair cells to receive effective vibration stimulation. Sound vibrations are captured by the auricle which is passed on to the ear canal and hits the tympanic membrane so that the tympanic membrane vibrates. These vibrations are transmitted to the hearing bones which are related to each other. Next the stapes move the foramen ovale which also moves the perilimfe on the vestibuli scale. The vibration of the lymph can also separate the hair cells from the basilar membrane, which results in the disruption of ribbon synapses. At rest, the ends of Corti's hair cells twist, and with the push of the basement membrane, the ends of the hair cells become straight. These physical stimuli turns into electrical stimuli due to differences in the sodium and potassium ions which are transmitted to the branches of N. VIII, then continues the stimulation to the sensory center of hearing in the brain through the central nerve in the temporal lobe. As a result, the residual synapses cannot maintain optimal function and the encoding ability of hair cells becomes defective. This causes workers cannot understand language or cannot hear effectively when they are in noisy environment (Ding et al., 2019).

NIHL occurs due to various factors including difficulties that occur, the type of discussion (wideband, narrowband or impulse), duration of daily exposure, nature of environment in which exposure occurs, distance of the individual from the source of the noise, position of the ears relative to the sound waves, age, work period, history of illness (diabetes mellitus, hypertension, and hearing), washing, education, hobbies, and use of ear protection equipment ((Soeripto, 2008) (Salami et al ., 2015), (Goetsch, 2015) (Ibrahim et al., 2016),(Sari et al., 2017), (Koagouw et al., 2013), (Silitonga et 
al., 2014), (Asrun et al ., 2013), (Syah and Keman, 2017), (Adnyani, Made, Sri, and Adiputra, 2017), (Rahayu and Pawenang, 2016))

Noise-induced hearing loss can be detected using an audiometer. Audiometry is a standard test to detect and evaluate hearing loss. Audiometry is used to determine the auditory threshold of an individual to pure tones of $250-8000 \mathrm{~Hz}$ and sound levels between 10 (the hearing threshold of intact ears) and $110 \mathrm{~dB}$ (maximal damage). Air conduction is measured by ear phones placed on the ears, while bone conduction is measured by placing a vibrator in contact with the skull behind the ears. Each ear is evaluated separately and test results are reported on a graph known as an audiogram (Goetsch, 2015).

Employees who work in industries have great potential to experience hearing loss due to noise, as well as residents living nearby. One of the industries in Indonesia, PT Trisulatex, In order to

Table 1. The Decree of the Minister of Health No: PMK.70/2016 concerning Standard and Requirement of Industrial Occupational Environmental Health

\begin{tabular}{|c|c|c|}
\hline Denomination & $\begin{array}{c}\text { Noise Exposure } \\
\text { Duration per Day }\end{array}$ & Noise level (dBA) \\
\hline \multirow{6}{*}{ Hour } & 24 & 80 \\
\hline & 116 & 82 \\
\hline & 8 & 85 \\
\hline & 4 & 88 \\
\hline & 2 & 91 \\
\hline & 1 & 94 \\
\hline \multirow{6}{*}{ Minute } & 30 & 97 \\
\hline & 15 & 100 \\
\hline & 7.5 & 103 \\
\hline & 3.75 & 106 \\
\hline & 1.88 & 109 \\
\hline & 0.94 & 112 \\
\hline \multirow{9}{*}{ Second } & 28.12 & 115 \\
\hline & 14.06 & 118 \\
\hline & 7.03 & 121 \\
\hline & 3.52 & 124 \\
\hline & 1.76 & 127 \\
\hline & 0.88 & 130 \\
\hline & 0.44 & 133 \\
\hline & 0.22 & 136 \\
\hline & 0.11 & 139 \\
\hline
\end{tabular}

Source : Ministry of Health of Republic Indonesia (2016)

Note: Noise exposure may not exceed the $140 \mathrm{dBC}$ level even if only for a moment commemorate World Hearing Day, PT Trisulatex held a screening of 300 employees and residents around the factory. It aims to detect employees and residents who may experience noise-induced hearing loss early (Febriani, 2019).

PT. Multi Karya Asia Pacific Raya (PT. MKAPR) is known as a company that provides products and services for the oil and gas industry in Indonesia with a total workforce in Lodan-9 Workshop around 74 people. The Lodan-9 Workshop area is known to have different noise levels, which is $88-91 \mathrm{~dB}$ in the fabrication, pump, and engineering areas, and 90-102 $\mathrm{dB}$ in the function test area. Meanwhile, the threshold value of the noise intensity is $85 \mathrm{~dB}$ for 8 hours a day \{Kementerian Kesehatan Republik Indonesia (2016); Kementerian Ketenagakerjaan (2018)\}. From the MCU Data of workers in 2017-2018, it is known that $48(64.9 \%)$ workers experinced hearing loss $<5 \mathrm{~dB}, 24(32.4 \%)$ workers experienced hearing loss $>5 \mathrm{~dB}$ and 2 $(2.7 \%)$ workers experienced hearing loss $>10 \mathrm{~dB}$. From the description above, researchers interested in analyzing the factors associated with NIHL on workers at the Lodan-9 Workshop of PT. Multi Karya Asia Pacific Raya in 2019.

\section{METHODS}

The design of this study used a case-control design, which was carried out at PT MKAPR from January to April 2019. The population was workshop workers at PT. MKAPR with a sample of 52 respondents. The sampling technique in this study used purposive sampling, with the inclusion criteria in the case group were workers diagnosed with hearing loss by doctors and recorded in the examination of MCU of PT. MAKPR workers in 2018, while in the control group were workers who were not diagnosed with hearing loss. The exclusion criteria were respondents who were not working in the PT. MAKPR workshop and not willing to be observed and interviewed. The independent data (age, work period, noise intensity, and smoking habit) were collected through a questionnaire, while the dependent (NIHL) was by checking the medical check up's document. They were then analyzed through the chi-square test to find the relationship of the independent variables and the dependent variable. This research has gone through an ethical review process and was declared to have passed the ethical review under number 0239-19.248/DPKEKEP/FINAL-EA/UEU/VII/2019. 


\section{RESULT}

This study conducted on 52 samples as research subjects in March 2019. Based on table 2, we found in the case group, respondents at-risk age $50 \%$, while $50 \%$ of respondents who were not at risk. Respondents with a risk working period were $88.5 \%$ and, respondents with a non-risk working period were $11.5 \%$. As much as $76.9 \%$ of respondents had a risk smoking habit and, respondents with a risk nonsmoking habit was $23.1 \%$. Respondents who had a risk of noise intensity was $84.6 \%$ while, respondents who had no risk of noise intensity were $15.4 \%$. In the control group, we found that respondents with age at risk were $50 \%$, while respondents with no risk were $50 \%$. Respondents with a risk working period were $57.7 \%$ and, respondents with a non-risk working period were $42.3 \%$. Respondents with a risk smoking habit were $88.5 \%$ and, respondents with a risk non-smoking habit were $11.5 \%$. Respondents with a risk of noise intensity were $53.8 \%$ while, respondents with non-risk of noise intensity were $46.2 \%$.

\section{Age}

Based on Table 3, the highest proportion among workers who experienced NIHL incidence, was found in workers with at risk age of 14 people

Table 2. The Characteristic Frequency Distribution, Respondent Noise Intensity at PT MKAPR 2019

\begin{tabular}{ccccc}
\hline \multirow{2}{*}{ Variable } & \multicolumn{2}{c}{ Case } & \multicolumn{2}{c}{ Control } \\
\cline { 2 - 5 } & f & \% & f & $\%$ \\
\hline Age & 14 & 53.8 & 14 & 53.8 \\
At risk & 12 & 46.2 & 12 & 46.2 \\
Not at risk & 26 & 100 & 26 & 100 \\
\hline Total & & & & \\
\hline Work Period & 23 & 88.5 & 15 & 57.7 \\
At risk & 3 & 11.5 & 11 & 42.3 \\
Not at risk & 26 & 100 & 26 & 100 \\
\hline Total & & & & \\
\hline Smoking Habits & 20 & 76.9 & 23 & 88.5 \\
At risk & 6 & 23.1 & 3 & 11.5 \\
\hline Not at risk & 26 & 100 & 26 & 100 \\
\hline Total & 26 & 84.6 & 14 & 53.8 \\
\hline Noise Intensity & & 15.4 & 12 & 46.2 \\
\hline At risk & 260 & 26 & 100 \\
\hline Not at risk & 4 & & & \\
\hline Total & 26 & & & \\
\hline
\end{tabular}

(53.8\%). Meanwhile, for workers who did not experience NIHL, the highest proportion was found in workers at risk age of 14 people (53.8\%). From the chi square test results, it was found that there was no relationship between the age and NIHL incidence for workers at PT MKAPR in 2018. Bivariate results shows that Odds Ratio $(\mathrm{OR})=1$, which means that workers experience NIHL and workers who do not experience NIHL have the same risk.

\section{Work Period}

Based on Table 4, it is known that among the workers who experienced NIHL, the highest proportion was workers with at-risk work period of 23 people $(88.5 \%)$. Whereas, the workers who did not experience NIHL, the highest proportion was found in workers with at-risk work periods of 15 people $(57.7 \%)$. From the results of the chi-square test, it was perceived that there was a significant relationship between a work period and the incidence of NIHL for workers at PT MKAPR in 2018. The bivariate result shows Odds Ratio $(\mathrm{OR})=5.622$, which means that workers who work with at-risk work period ( $\geq 5$ years) have a risk of 5.622 times having NIHL compared to workers with no-risk work period ( $<5$ years).

Table 3. The Relationship between Age and NIHL Incidence in Workers at PT. MKAPR Jakarta 2019

\begin{tabular}{|c|c|c|c|c|c|c|}
\hline \multirow{3}{*}{ Age } & \multicolumn{4}{|c|}{ NIHL Incidence } & \multirow{3}{*}{$\begin{array}{c}\text { OR } \\
\left(\begin{array}{c}95 \% \\
\text { CI })\end{array}\right.\end{array}$} & \multirow{3}{*}{ p-value } \\
\hline & \multicolumn{2}{|c|}{ NIHL } & \multicolumn{2}{|c|}{ Not NIHL } & & \\
\hline & n & $\%$ & n & $\%$ & & \\
\hline At risk & 14 & 53.8 & 14 & 53.8 & 1.547 & \\
\hline $\begin{array}{c}\text { Not at } \\
\text { risk }\end{array}$ & 12 & 46.2 & 12 & 46.2 & $\begin{array}{c}(0.336- \\
2.976)\end{array}$ & 1 \\
\hline Total & 26 & 100 & 26 & 100 & & \\
\hline
\end{tabular}

Table 4. Relationship between Work Period and NIHL Incidence in Workers at PT. MKAPR Jakarta 2019

\begin{tabular}{|c|c|c|c|c|c|c|}
\hline \multirow{3}{*}{$\begin{array}{c}\text { W o r k } \\
\text { Period }\end{array}$} & \multicolumn{4}{|c|}{ NIHL Incidence } & \multirow{3}{*}{$\begin{array}{c}\text { OR } \\
(95 \% \\
\text { CI) }\end{array}$} & \multirow{3}{*}{ p-value } \\
\hline & \multicolumn{2}{|c|}{ NIHL } & \multicolumn{2}{|c|}{ Not NIHL } & & \\
\hline & $n$ & $\%$ & $n$ & $\%$ & & \\
\hline At risk & 23 & 88.5 & 15 & 57.7 & 5.622 & \\
\hline $\begin{array}{c}\text { Not at } \\
\text { risk }\end{array}$ & 3 & 11.5 & 11 & 42.3 & $\begin{array}{l}(1.342- \\
23.559)\end{array}$ & 0.029 \\
\hline Total & 26 & 100 & 26 & 100 & & \\
\hline
\end{tabular}


Table 5. The Relationship between Smoking Habits and NIHL Incidence on Workers at PT. MKAPR Jakarta 2019

\begin{tabular}{|c|c|c|c|c|c|c|}
\hline \multirow{3}{*}{$\begin{array}{c}\text { Smoking } \\
\text { Habits }\end{array}$} & \multicolumn{4}{|c|}{ NIHL Incidence } & \multirow{3}{*}{$\begin{array}{c}\text { OR } \\
\left(\begin{array}{c}95 \% \\
\text { CI) }\end{array}\right.\end{array}$} & \multirow{3}{*}{ p-value } \\
\hline & \multicolumn{2}{|c|}{ Case } & \multicolumn{2}{|c|}{ Control } & & \\
\hline & n & $\%$ & n & $\%$ & & \\
\hline Smoking & 20 & 76.9 & 23 & 88.5 & 0.435 & \\
\hline $\begin{array}{c}\text { Not } \\
\text { smoking }\end{array}$ & 6 & 23.1 & 3 & 11.5 & $\begin{array}{c}(0.096- \\
1.168)\end{array}$ & 0.465 \\
\hline Total & 26 & 100 & 26 & 100 & & \\
\hline
\end{tabular}

Table 6. The Relationship between Noise Intensity and NIHL Incidence on workers at PT. MKAPR Jakarta 2019

\begin{tabular}{|c|c|c|c|c|c|c|}
\hline \multirow{3}{*}{$\begin{array}{c}\text { N o i s e } \\
\text { Intensity }\end{array}$} & \multicolumn{4}{|c|}{ NIHL Incidence } & \multirow{3}{*}{$\begin{array}{c}\text { OR } \\
(95 \% \\
\text { CI) }\end{array}$} & \multirow{3}{*}{ p-value } \\
\hline & \multicolumn{2}{|c|}{ Case } & \multicolumn{2}{|c|}{ Control } & & \\
\hline & n & $\%$ & $\mathrm{n}$ & $\%$ & & \\
\hline $\begin{array}{c}\text { Not } \\
\text { appropriate } \\
\text { to TLV }\end{array}$ & 22 & 84.6 & 14 & 53.8 & 4.714 & 0.035 \\
\hline $\begin{array}{c}\text { Appropriate } \\
\text { to TLV }\end{array}$ & 4 & 15.4 & 12 & 46.2 & $\begin{array}{l}(1.266- \\
17.561)\end{array}$ & \\
\hline Total & 26 & 100 & 26 & 100 & & \\
\hline
\end{tabular}

\section{Smoking Habits}

Based on Table 5, we found that workers who experienced NIHL, the highest proportion was 20 workers $(76.9 \%)$ who have smoking habits, while workers who did not experience NIHL, the highest proportion was workers who have smoking habits of 23 people (88.5\%). From the results of the chisquare test, it found that there was no relationship between smoking habits and NIHL incidence on workers at PT MKAPR in 2018. Bivariate result of $\mathrm{OR}=0.435$ means workers who have smoking habits were protective against NIHL compared to workers who did not have one.

\section{Noise Intensity}

Based on Table 6, it was known that workers who experienced NIHL, the highest proportion was 22 workers $(84.6 \%)$ with the intensity of noise which is not appropriate to TLV. Whereas, workers who did not experienced NIHL, the highest proportion was 14 workers $(53.8 \%)$ with the intensity of noise which is not appropriate to TLV. From the results of the chi-square test, it found that there was a relationship between noise intensity and NIHL incidence for workers at PT MKAPR in 2018. In bivariate results, there was Odds Ratio $(\mathrm{OR})=4.716$, which means that workers who worked with the noise intensity which not appropriate to TLV had a risk 4.716 times experiencing NIHL compared to workers who worked with the noise intensity appropriat to TLV.

\section{DISCUSSION}

\section{The Relationship between the Age and NIHL Incidence}

Hearing begins with sound waves in the air, then enters the external ear canal and strikes the tymphanic membrane, causing it to vibrate, and then the ibration of the tymphanic membrane causes the malleus to vibrate, and then the incus and the stapes. The motion of the stapes against the oval window initiates movement of the perilymph and endolymph in the cochlea. Then, these water waves stimulate movement of the membranes and hair cells in the organ of corti, which converts the stimulus into a nerve impulse, and then they are conducted to the auditory area in the temporal lobe of the brain, where the sound is received and interpreted.

Age is one of risk factors for workers to get disease due to noise. Someone will experience a pathological transformation in the auditory organ as someone ages. People over the age of 40 will experience a significant hearing loss that makes them more susceptible to Noise Induced Hearing Loss. The tympanic membrane shows thinning and stiffness, while the auditory muscles experience artistic joints. The most vulnerable part is the Corti organ in the cochlea which transfers sound in the form of electrical impulses which will be translated by the auditory nerve in the brain. Even without noise exposure, hearing loss increases with age (presbycusis) ((Harrianto, 2013), (Suwento, 2007), (Soedirman, 2012)).

The results showed that among workers who experienced NIHL incidence, the highest proportion was found in workers with at risk age of 14 people (53.8\%). Meanwhile, for workers who did not experience NIHL, the highest proportion was workers who were at risk by 14 respondents $(53.8 \%)$. Workers experienced NIHL at the age $>$ 40 years with a percentage of $73.1 \%$ and OR of 1.547 which means that age has a risk of 1.547 times cause a NIHL. The results of this study are in line with Waskito (2005) which stated that age $>40$ years are more at risk of experiencing NIHL, with OR value of 7.3 means that workers with age $>40$ years are 7.3 times more at risk of hearing loss than 
age $\leq 40$ years old. This difference may be due to differences in respondents' characteristics and other factors that may cause NIHL such as exposure to noise intensity and work period.

This is in line with Tambunan (2005) that the aging process is a dominant risk factor as a cause of hearing loss. Workers who are more than 40 years old will be more easily deaf due to noise. The most common cause of age-related hearing loss is presbycusis. It can increase the hearing threshold of $0.5 \mathrm{db}$ each year, starting from age of 40 years. Therefore, in calculating the level of disability or compensation a $0.5 \mathrm{db}$ correction factor is used every year for workers older than 40 years. Therefore, PT MKAPR has taken control by making a silent box, but due to cost limitations there are still machines that have not used the silent box. Therefore, researchers suggest that company limits the work time of workers in high noisy areas. In addition, company can control the risk by reducing noise at the source by installing a muffler or reducing structure-borne vibration by installing vibration mounts and providing lubrication.

\section{Relationship between Work Period and NIHL Incidence}

The results of the study stated that among the workers who experienced NIHL, the highest proportion was workers with at-risk work period 23 people $(88.5 \%)$. Whereas, the workers who did not experience NIHL, the highest proportion was found in workers with at-risk work periods by 15 people (57.7\%) and Odds Ratio (OR) of 5, which means that workers with at risk work period have a risk of 5 times experiencing NIHL compared to workers who are not at risk work period. This study is in line with Septiana and Widowati (2017) which stated that work period caused Noise-Induced Hearing Loss in workers who work $>10$ years at PT. Indonesia Power UBP Semarang, with Odds Ratio (OR) value of 3.656, means that workers who work $>10$ years are having a risk of Noise Induced Hearing Loss 3.656 times greater than workers who work $\leq 10$ years to experience Noise-Induced Hearing Loss.

Research conducted by Marisdayana et al., (2016) also stated that workers with work period $>14$ years related to the incidence of hearing loss at PT. X, with Odds Ratio (OR) value of 2.8 which means that workers with work period $>14$ years were have a risk of experiencing hearing loss 2.8 times greater compared to workers with work period $\leq 14$ years. Likewise, the study by Waskito (2005) states that workers with work period $>20$ years is a risk factor for hearing loss, with Odds Ratio (OR) value of 5.7 means workers with work period $>20$ years are 5.7 times more at risk compared to workers with work period $\leq 20$ years.

Harrianto (2013) mentioned that the longer the work period in noisy places, the greater the risk of hearing loss. This generally occurs after workers experience noise exposure for more than 5 years, progression when noise exposure is stopped and becomes permanent if it is continuously exposed for more than 10 years.

Sound that is too noisy and prolonged can cause stimulation of the area near the reception area of the premiere hearing which will cause a sensation of rumbling and ringing, with the onset of this sound sensation will also cause vetralateralis thalamus nucleus stimulation which will cause impulse inhibition of muscle coils. In other words, this will move or strengthen the inhibitory system that is in the thalamus (Ganong, 2008).

If a worker extends the work time than the working hours or overtime, it usually results in inefficient, ineffective work and decreased the work productivity. It also causes workers to have a tendency for fatigue, health problems, illness and accidents and dissatisfaction. Meanwhile, we know that workers are important asset in enhancing competitiveness. They are national assets that support human development index which is an indicator of the nation's competitiveness (Suma'mur, 2009).

PT MKAPR has implemented a control program in the form of administration by implementing a work rotation system, engineering control that is the use of a silent box for engines with noise levels above TLV and the application of the use of hearing protector such as earplugs and earmuffs. The control program is also supported by regular MCU implementation and workforce registration in the BPJS health and employment program. However, researchers suggest that HSE do a hearing lost prevention program such as training to educate and motivate workers. They have to supervise the use of hearing protectors on workers and provide rewards for workers who comply with the use of those.

\section{The Relationship between Smoking Habits and NIHL Incidence}

Based on the results, it was found that workers who experienced NIHL, the highest proportion was found in workers who have smoking habits by 
20 people $(76.9 \%)$. Meanwhile, workers who did not experience NIHL, the highest proportion was found in workers who had a smoking habits by 23 people $(88.5 \%)$ The results showed that there was no relationship between smoking habits and NIHL incidence in workers at PT MKAPR in 2018. The bivariate results were Odds Ratio $(\mathrm{OR})=0.435$ which means that workers who had smoking habits were protective of NIHL compared to workers who do not have smoking habits. This study is not in line with Waskito (2005), who mentioned that there was a relationship between smoking status in workers and hearing loss, with Odds Ratio (OR) value of 3.38 , which means that workers who smoke had a risk of 3.38 times greater than workers who did not smoke.

Smoking is one of the habits commonly found in daily life both among men, women, young and old, elderly, rich and poor. Cigarettes contain around 3000 types of chemicals, with nicotine and carbon monoxide being important ingredients in the process of damage to the hearing organs. Nicotine has ototoxic properties and constricts blood vessels thereby reducing blood supply to organs. Carbon monoxide will form carboxy-hemoglobin, which will reduce cell-level oxygen availability. The influence of chemicals in cigarettes will cause damage to the cochlea organ (Bustan, 2015).

The world health organization states that tobacco kills more than five million people per year, and is projected to kill 10 million by 2020 . Smokers are classified as light smokers if they smoke less than 10 cigarettes per day, smokers are smoking 10-20 cigarettes and heavy smokers if it is more than 20 cigarettes (Bustan, 2015). Based on the result of the study, among 43 workers who smoked, 37 respondents (86\%) smoked cigarettes of 1-10 cigarettes a day while 6 respondents $(13.9 \%)$ smoked cigarettes of 11-20 cigarettes a day. And this smoking habit has been done for more than 3 years. They smoke because smoking becomes a habit when gathering and one way to relieve their stress.

Although the results of the study stated that there was no relationship, but workers who had smoking habits had a risk of 3.38 times greater than workers who did not smoke. Therefore, researchers suggest that companies conduct health promotion regarding smoking in order to increase worker's awareness about the impact of smoking on Noise Induced Hearing Loss. In addition, they can create smoke-free program policies that aim to create a smoke-free condition such as the development of a No-Smoking Zone at PT MKAPR.

\section{The Relationship between Noise Intensity and NIHL Incidence}

Based on the result, it was known that workers who experienced NIHL, the highest proportion was found in workers with the intensity of noise which was not appropriate to TLV by 22 people (84.6\%). Meanwhile, workers who did not experience NIHL, the highest proportion was found in workers with the intensity of noise which was not appropriate to TLV by 14 people $(53.8 \%)$. Noise Intensity was related to NIHL incidence on workers at PT MKAPR in 2018, with Odds Ratio (OR) value $=4.716$, which means workers that work with noise intensity which is not appropriate to TLV had a risk 4.716 times experiencing NIHL compared to workers who work with appropriate noise intensity to threshold limit value.

Sound or noise is heard as a stimulus to the nerve cell of the listener in the ear by longitudinal waves caused by vibrations from the source of the sound or sound and these waves propagate through the air media or other conductor, and when sound is undesired because of interference or arising out of the person concerned, then such sounds are declared as noise. So, noise is sound whose existence is not desired (noise is unwanted sound). The human ear is able to hear sound frequencies or sounds between $16-20,000 \mathrm{~Hz}$. The intensity or current of energy per unit area is usually expressed in a logarithmic unit called decibels $(\mathrm{dB})$ by comparing it to the standard strength of 0.0002 dine (dyne) $/ \mathrm{cm}^{2}$ which is the sound strength with a frequency of $1,000 \mathrm{~Hz}$ which can be heard by normal ears (Suma'mur, 2009). The threshold value in noise is a workplace factor standard that is acceptable to labor without causing illness or health problems, in daily work for a time not exceeding 8 hours a day or 40 hours a week (Ministry of Manpower, 2018).

This study is in line with Marisdayana et al., (2016) and Rastogi (2016) which stated that noise exposure intensity had a significant relationship to hearing loss. Workers who work in environments with noise exposure intensity exceeding TLV (85 dB) had a 2.7 times higher risk of suffering from hearing loss compared to respondents who work in environments with noise exposure intensity that did not exceed TLV.

In the Lodan-9 Workshop area at PT MKAPR, there was a type of intermittent noise with different noise levels, where the noise level from the function test area reached $102 \mathrm{~dB}$ and the noise level from the fabrication area, pump area and engine area 
reached $91 \mathrm{~dB}$. The function test process is a sound source that needs to be considered by the company with a noise level reaching $102 \mathrm{~dB}$ with a process that takes time between 2-3 hours for each engine. From several measurement points conducted by the company using sound level meter, it is known that at the first measuring point which is 6 meters from the sound source (function test area), the noise level reaches $95-97 \mathrm{~dB}$, at the second measuring point which is 10 meters from the sound source the noise level reaches $86-90 \mathrm{~dB}$, and at the second measuring points which is 14 meters from the sound source it is known the noise levels range from 62$86 \mathrm{~dB}$. Meanwhile, according to Decree of the Minister of Manpower No: PMK.8/2018 concerning Environmental Occupational Health and Safety, it is stated that the noise intensity is $85 \mathrm{~dB}$ for 8 hours a day (Ministry of Manpower, 2018).

Anizar (2012) mentioned that noise exposure intensity may cause hearing disorders stated that the intensity of noise exposure can cause hearing loss of conductive deafness type that occurs when there is interference or damage to the outer ear and the typhoid membrane located in the middle ear, the intensity of noise that occurs in a short time can cause trauma to the external ear to the drum sensorineural ears and deafness that occur when there is secondary damage to the cochlea, auditory nerve, and brain stem so that the sound cannot be processed properly. In addition, it can also cause mixed deafness due to a combination of conductive deafness and sensorineural deafness. In addition, workers who had a history of high blood pressure or hypertension and exposed to high-intensity noise for a long time, which can cause them experience cardiovascular diseases \{Yousefi and Hassanzadeh (2013); Wang et al., (2018)\}

PT MKAPR has carried out risk control with engineering control that is providing a silent box to reduce noise up to $20 \mathrm{Db}$ generated by the machine when the function test is in an open area of 3 units in an area that has a noise intensity reaches 102 $\mathrm{Db}$. Meanwhile, for other areas such as fabrication, pump, and engine area with noise levels ranges from 88-91 dB more focuses on the use of APT in the form of ear plugs, this is because the noise level in the area is not as big as function test process, in addition to the price of 1 unit of silent box that is quite expensive which is around IDR13,000,000. Therefore, researchers suggest that companies limit the work hours of workers in the area, namely by creating procedures with a noise intensity of 88-91
$\mathrm{Db}$, workers are only allowed to work for 2-4 hours a day.

\section{CONCLUSION}

We can conclude that work period and noise intensity have correlation with noise-induced hearing loss. But age and smoking habit do not have correlation with noise induced hearing loss on workers at workshop 9 PT MKAPR. The higher the noise exposure experienced by workers and the longer the worker in an area that has high noise intensity, the more likely the worker experiencing Noise-Induced Hearing Loss.

\section{ACKNOWLEGEMENT}

Researchers would like to thank all respondents for their participation in this research. And our most gratitude to God Almighty and family as the biggest supporters in the process of writing this paper.

\section{REFERENCES}

Adnyani, A. L., Made, L., Sri, I., \& Adiputra, H. (2017). Prevalensi Gangguan Fungsi Pendengaran Akibat Kebisingan Lingkungan Kerja Pada Pekerja Kayu Di Desa Mas Kecamatan Ubud Kabupaten Gianyar. E-Journal Medika Udayana, 6(12),pp.144-147.

Anizar. (2012). Teknik Keselamatan Dan Kesehatan Kerja di Industri. Yogyakarta: Graha Ilmu.

Asrun, A., Zamrud, L. ., \& Sudayasa, I. P. (2013). Faktor-Faktor Risiko Yang Berhubungan Dengan Kejadian Gangguan Pendengaran Pada Karyawan Tambang. Medula (Jurnal Ilmiah Fakultas Kedokteran Universitas Halu Oleo), 1(1), pp.14-19.

Bustan, M. N. (2015). Manajemen Pengendalian Penyakit Tidak Menular. Jakarta: Rineka Cipta.

Ding, T., Yan, A., \& Liu, K. (2019). What Is NoiseInduced Hearing Loss? British Journal Of Hospital Medicine, 80(9), pp.525-529.

Febriani, R. N. (2019). Karyawan Dan Warga Di Sekitar Pabrik Berpotensi Besar Alami Gangguan Pendengaran. Bandung: Pikiran-Rakyat.

Ganong, W. F. (2008). Fisiologi Kedokteran. Jakarta: Penerbit Buku Kedokteran Egc.

Goetsch, L. D. (2015). Occupational Safety And Health. Edinburgh: Pearson.

Harrianto, R. (2013). Buku Ajar Kesehatan Kerja. Jakarta: EGC. 
Ibrahim, H., Basri, S., \& Hamzah, Z. (2016). FaktorFaktor yang Berhubungan dengan Keluhan Gangguan Pendengaran pada Tenaga Kerja Bagian Produksi PT . Japfa Comfeed. Al-Sihah : Public Health Science Journal, 8(2),pp.121-134.

Ministry of Health (2016) Number 70 Year 2016 tentang Standar Dan Persyaratan Kesehatan Lingkungan Kerja Industri. Jakarta: Ministry of Health.

Ministry of Manpower (2018). Number 5 Years 2018 tentang Keselamatan Dan Kesehatan Kerja Lingkungan Kerja. Jakarta: Ministry of Manpower.

Koagouw, I. A., Wenny, S., and Rumampuk, J. F. (2013). Pengaruh Kebisingan Mesin Las Disel Listrik Terhadap Fungsi Pendengaran Pada Pekerja Bengkel Las Di Kecamatan Mapanget Kota Manado. Jurnal e-Biomedik (eBM), 1(1), pp. 379-386.

Marisdayana, R., Suhartono, S., \& Nurjazuli, N. (2016). Hubungan Intensitas Paparan Bising Dan Masa Kerja Dengan Gangguan Pendengaran Pada Karyawan PT. X. Jurnal Kesehatan Lingkungan Indonesia, 15(1), pp. 22-27.

National Institute For Health Research \& Development. (2013). Riset Kesehatan Dasar (National Health Survey). Jakarta: Ministry Of Health Republic Of Indonesia.

Plog, B., Niland, J., and Quinlan, P. (2012). Fundamentals Of Industrial Hygiene, 6th Edition. Usa : National Safety Council

Rahayu, P., and Pawenang, E. T. (2016). Faktor Yang Berhubungan Dengan Gangguan Pendengaran Pada Pekerja Yang Terpapar Bising Di Unit Spinning I Pt. Sinar Pantja Djaja Semarang. Unnes Journal Of Public Health, 5(2), pp. 140-148.

Rastogi, S., Janat, R., and Kumar VVD, P. (2016). Prevalence Of Onihl In Manufacturing Industry. Journal Of Otolaryngology-Ent Research, 5(2), pp. 1-5.

Rizi, H. A. Y., and Hassanzadeh, A. (2013). Noise Exposure as a Risk Factor of Cardiovascular Diseases in Workers. Journal of Education and Health Promotion, 2(March), pp. 1-4.
Salami, I. R. S., \& Dkk. (2015). Kesehatan Dan Keselamatan Lingkungan Kerja. Yogyakarta: Gadjah Mada University Press.

Sari, M. A., et.al. (2017). The Correlation of Smoking and Noise Induced Hearing Loss on Workers at A Palm Oil Factory X in Medan-Indonesia. Bali Medical Journal, 6(3), pp. 637-640.

Septiana, N. R., and Widowati, E. (2017). Gangguan Pendengaran Akibat Bising. Higeia:Journal Of Public Health Research And Development, 1(1), pp.73-82.

Silitonga, N., et.al. (2014). Hubungan Kebisingan Dengan Pendengaran Pekerja (Studi Kasus Diskotik A, B , C Di Kota Medan). Thesis. Medan: Faculty of Medicine, Universitas Sumatera Utara.

Soedirman. (2012). Higiene Perusahaan. Jakarta: El Musa Press.

Soeripto, M. (2008). Higiene Industri. Jakarta: Balai Penerbit Fakultas Kedokteran Universitas Indonesia.

Sulaiman, M. R. (2017). Kondisi Terkini Gangguan Pendengaran Dan Ketulian Di Indonesia. Jakarta: DetikHealth.

Suma'mur. (2009). Higiene Perusahaan Dan Kesehatan (Hiperkes). Jakarta: Sagung Seto.

Suwento, R. (2007). Standar Pelayanan Kesehatan Indera Pendengaran Di Puskesmas. Jakarta: Komnas PGPKT.

Syah, P. B., and Keman, S. (2017). Pengaruh Penggunaan Pelindung Telinga dan Earphone Terhadap Noise Induced Hearing Loss Dan Tinitus Pada. Pekerja Bengkel. Jurnal Kesehatan Lingkungan, 9(1), pp. 21-30.

Wang, F., et,al., (2018). Occupational Noise Exposure and Hypertension: a Case-Control Study. Journal of Public Health and Emergency, 2(December), pp. 30-30.

Waskito, H. (2005). Faktor-faktor yang Mempengaruhi Gangguan Pendengaran Sensorineural Pekerja Perusahaan Minyak. Kesmas : Jurnal Kesehatan Masyarakat Nasional, 2(5), pp. 220-225. 